\title{
A sötét hármas megjelenése egyetemi hallgatók körében
}

\section{The appearance of dark triad among university students}

\author{
M. UJHELYI \\ Debreceni Egyetem, Gazdaságtudományi Kar, Vezetés- és Szervezéstudományi Intézet, \\ ujhelyi.maria@econ.unideb.hu
}

Absztrakt. Az elmúlt évtizedek személyiség kutatásában előkelő helyet foglal el az úgynevezett „Sötét Hármas” nárcizmus machiavellizmus, és pszichopátia - vizsgálata. E társadalmilag nemkívánatos, de mindenkiben bizonyos mértékig meglévő jellemvonásoknak a munka világában is jelentős szerepe van. Dark Triad tagnak tekinti a szakirodalom azokat, akik mindhárom jellemzőben erösek. Tanulmányomban a Debreceni Egyetem Gazdaságtudományi Karának hallgatói körében, e „Sötét Hármas” (Dark Triad) mérésére kidolgozott, validált Dirty Dozen kérdöív felhasználásával végzett vizsgálat eredményeit mutatom be. Kutatásomban arra keresem a választ, hogy milyen mértékben jelennek meg ilyen személyiségvonások az általam vizsgált sokaságban. Kimutathatók-e különbségek a háttér változóktól (kor, nem, szak...) függően? Az eredmények összhangban állnak-e a nemzetközi kutatásokban leírtakkal?

\begin{abstract}
In recent decades, the examination of the so called "Dark Triad" - narcissism Machiavellianism and psychopathy - occupies a prominent place in personality research. These socially undesirable characteristics, which, to some extent are present in everybody, can play an important role in the workplace. Dark Triad members are those, according to the literature who are strong in all three features. In my paper I will present the results of a study I conducted among the students of University of Debrecen Faculty of Economics and Business. I analyse the Dark Triad characteristics of students with the help of a validated measure the Dirty Dozen. In my research I try to find answer to what extent these personality traits appear in the examined sample? Is there any difference depending on the background variables (age, sex, educational programme ...)? Are my results consistent with those described in international research?
\end{abstract}

\section{Bevezetés}

Számos egyéni magatartást meghatározó tényező létezik, melyek hatást gyakorolnak arra, hogy hogyan boldogulunk életünkben, és mennyire tudunk eredményesen hozzájárulni a szervezetek sikereihez. Ezen tényezők között kiemelt fontossággal bír a személyiség, tulajdonságaink viszonylag stabil készlete [1], ami különböző mértékben tesz minket alkalmassá bizonyos munkakörök betöltésére [2]. Általában nem beszélünk előnyös, vagy kedvezőtlen személyiség vonásokról, mert 
bizonyos jellemzőben mutatott erősségünk a dimenzió másik végén gyengeséget jelent. Mégis a társadalom megítéli ezeket a személyiség vonásokat. Az elmúlt évtizedekben az érdeklődés középpontjába került több, társadalmilag nemkívánatos személyiségvonás - a nárcizmus machiavellizmus, és pszichopátia - vizsgálata. Negatív megítélésüknek köszönhetően a kutatók a „Sötét Hármas” (Dark Triad) elnevezést adták nekik, bár nem mindig bukkannak fel együtt [3]. Tanulmányozásának különleges jelentőséget ad, hogy a média, a politika és a gazdasági élet szereplői között gyakran találkozhatunk e személyiségjegyeket hordozó hírességekkel, akik egyértelműen profitáltak Sötét Hármas tagságukból [4]. E személyiség elmélet és a mérésére kidolgozott Dirty Dozen [5] kérdőív népszerűségéből ötletet merítve 2017 februárjában empirikus kutatást indítottunk a Debreceni Egyetem Gazdaságtudományi Kar hallgatói körében. Távolabbi tervünk a személyiségvonások és az etikus magatartás közötti kapcsolat vizsgálata. Jelen tanulmányomban a Sötét Hármas személyiség megjelenését vizsgálom a mintámba. Kutatási kérdéseim a következők:

- Milyen mértékben jelennek meg a „Sötét Hármas” személyiség vonások a DE GTK általam vizsgált hallgatói körében?

- Kimutathatók-e különbségek férfiak és nők között?

- Kimutathatók-e különbségek a szakok között?

- Kimutathatóak-e különbségek a kor függvényében?

- Az eredmények összhangban állnak-e a nemzetközi kutatásokban leírtakkal?

\section{Elméleti áttekintés}

Jellemvonásaink eszközként szolgálnak arra, hogy a csoportokon belül biztosítsuk helyünket, kapcsolatot találjunk társainkhoz. Egyes emberek mindezeket a problémákat a társadalom számára előnyös eszközökkel igyekeznek elérni, együttműködésre, tudatosságra törekednek, mások viszont társadalmilag nem preferált stratégiát alkalmaznak [5]. Ez utóbbiak közzé tartoznak azok, akikre erősen jellemző a machiavellizmus, a nárcizmus vagy a pszichopátia [6]. E személyiségvonások vizsgálata már hosszabb ideje elindult. A velük kapcsolatos társadalmi idegenkedés miatt nevezte el Paulhus és Williams [7] Sötét Hármasnak (Dark Triad) ezt a három jellemvonást. Mindegyikben fellelhető bizonyos mértékű rosszakarat, ami direkt módon hat az egyének közötti magatartásra.

A machiavellizmus, mint személyiségvonás Niccolo Machiavelliről kapta nevét, aki a tizenhatodik században írt arról hogyan lehet hatalomhoz jutni és hatalmat gyakorolni [3]. Az erősen machiavellisták pragmatikusak, érzelmi távolságot tartanak és álláspontjuk szerint a „cél szentesíti az eszközt”. Kutatások bizonyítják, hogy könnyen manipulálnak, gyakran nyernek, nehezen meggyőzhetőek [8]. Viszonylag sikeres karriert futnak be, különösen, ha strukturálatlan, kevésbé szervezett körülmények között dolgoznak [6]. Könnyen csalnak, hazudnak, cserbenhagynak másokat, de rendszeresen nem mutatnak túlzottan negatív antiszociális magatartást [9].

A narcisztikus személyeket saját nagyszerűségükbe, felsőbbrendűségükbe vetett hit jellemez, mások csodálatára vágynak [10]. Kutatások igazolják, hogy másoknál karizmatikusabbak [11]. Komplex döntések esetén alkalmazkodóbbak és jobb döntéseket hoznak [12]. Bizonyos esetekben az agresszivitással is kapcsolatba hozhatók. Bushman és társai [13] kimutatták, hogy az erősen 
narcisztikus személyek agresszívebbek voltak társaiknál, de csak akkor, amikor sértésekkel, vagy megalázással provokálták őket és agressziójuk a kritizáló felé irányult.

A Sötét Hármas utolsó tagja a pszichopátia, ami mások és a szabályozó mechanizmusok iránti érdektelenségben nyilvánul meg. Lobbanékonyság és bűntudat vagy lelkiismeret hiánya jellemzi őket, amikor tetteikkel másoknak kárt okoznak. A személyes kapcsolataikban jó benyomást tudnak kelteni, beszédesek, karizmatikusak. Érzelmileg sekélyesek, gyakran élősködő életstílust folytatnak és akár bűncselekményekben is részt vesznek, hogy céljaikat elérjék [6]. [14].

Bár a Sötét Hármas jellemzőket általában társadalmilag nemkívánatosnak tartjuk, kutatások kimutatták, hogy szervezeti kontextusban előnyhöz juthatnak az ilyen tulajdonságokkal rendelkező emberek [4]. A vezetők és menedzserek általában narcisztikusabbak, és az erősebben narcisztikus személyek jobb üzleti döntéseket hoznak [12]. Mindhárom Sötét Hármas tag jól prosperálhat üzleti környezetben, különösen, ha a munka racionális, érzelemszegény magatartást igényel [6].

A kutatásokból nem derül ki egyértelmúen, hogy a népesség mekkora hányadára jellemzőek ezek a személyiségvonások. Boddy [15] a pszichopatákra vonatkozóan közöl becsléseket. Véleménye szerint a népesség körében arányuk 1\% körüli, de magasabb beosztásokban sokkal nagyobb arányban jelennek meg. Bizonyos szervezetek, konkrétabban a nagy pénzügyi szervezetek vonzóak számukra. Férfiak körében mindhárom jellemző gyakoribb, de különösen a nárcizmus esetén a nemek közötti különbség csökken [16].

\section{Adatok és módszer}

Empirikus vizsgálatomhoz a Dirty Dozen [5] magyarra fordított változatát használtam. Hét fokozatú Likert-skálán kellett a válaszadóknak bejelölni, hogy mennyire jellemzőek rájuk a felsorolt megállapítások. A 12 kérdésből 4-4 méri a nárcizmust machiavellizmust, és pszichopátiát. A kérdések a következők:

Machiavellizmus

- 1. Hajlamos vagyok manipulálni másokat, hogy előrébb jussak.

- 5. Éltem már megtévesztéssel vagy hazugsággal, hogy előrébb jussak.

- 7. Hízelegtem már azért, hogy előrébb jussak.

- 10. Hajlamos vagyok kihasználni másokat, hogy elérjem a saját céljaimat.

- Pszichopátia

- 2. Jellemzően nem érzek lelkiismeret furdalást.

- 4. Nem szoktam foglalkozni a tetteim erkölcsi oldalával.

- 6. Általában könyörtelen vagy érzéketlen vagyok.

- 9. Általában cinikus vagyok.

- Nárcizmus

- 3. Azt akarom, hogy mások csodáljanak engem. 
- 8. Jellemző rám, hogy a hatalmat és az elismerést keresem.

- 11. El szoktam várni, hogy mások különleges szívességeket tegyenek nekem.

- 12. Azt akarom, hogy mások odafigyeljenek rám.

Egy-egy személyiségjellemzőre 4-28 pontot lehetett adni, az összes elérhető pontszám pedig 12-84 pont között volt. A kutatásokban 45 ponttól tekintik erősnek a Sötét Hármas jellemzőket. Elemzésemben az erre vonatkozó eredményeket is bemutattam, de szigorúbb feltételek szerint azt tekintettem Sötét Hármas tagnak, aki mindhárom jellemző esetén elérte a 15 pontot. A kérdőív kitöltése mellett néhány háttér adatot is kértem a válaszadóktól. Az adatgyűjtést személyesen én végeztem a Gazdaságtudományi Kar alapszakos Szervezeti magatartás óra, valamint a mesterszakos Változásmenedzsment óra keretében.

A kérdőívek elemzésénél egyszerű leíró statisztikákat, független mintás $t$-tesztet és ANOVA elemzést használtam.

\begin{tabular}{|l|l|l|l|}
\hline Kor (év) & Férfi & Nő & Összesen \\
\hline 19 & 5 & 18 & 23 \\
\hline 20 & 15 & 44 & 59 \\
\hline 21 & 15 & 39 & 54 \\
\hline 22 & 5 & 18 & 23 \\
\hline 23 & 11 & 11 & 22 \\
\hline 24 & 5 & 5 & 10 \\
\hline 25 & 0 & 6 & 6 \\
\hline 26 & 1 & 2 & 3 \\
\hline 27 & 0 & 1 & 1 \\
\hline 28 & 0 & 2 & 2 \\
\hline 42 & 1 & 0 & 1 \\
\hline 43 & 0 & 1 & 1 \\
\hline 45 & 1 & 0 & 1 \\
\hline 1. táblázat: A minta kor és nemek szerinti megoszlása (fó)
\end{tabular}

211 kérdőív gyűlt össze (a nem megfelelően kitöltött kérdőíveket kizártam az elemzésből). A válaszadók közül 60 férfi, 150 nő (egy válaszadó nem jelölte be a nemét). A megkérdezettek 19 és 45 év közöttiek, többségük 20-21 éves, átlag életkoruk 21,57 év (szórás 3,19, módusz 20, medián 21 év, hiányzó adat 5). A válaszadók megoszlását kor és nem szerint az 1. Táblázat mutatja.

A mintába 9 szak hallgatói kerültek bele. Nemek és szakok szerinti megoszlásukat a 2. Táblázat szemlélteti. A szakok elnevezésének rövidítése a következő: GM: Gazdálkodási és menedzsment 
alapszak, PSZ: Pénzügy Számvitel alapszak, NG: Nemzetközi gazdálkodási alapszak, KM: Kereskedelem és marketing alapszak, PSZ-FOSZ: Pénzügy és számvitel felsőoktatási szakképzés, VSZ: Vezetés és szervezés mesterszak, MBA: Master of Business Administration, EET: Emberi erőforrás tanácsadó mesterszak, BIOT: Biotechnológia mesterszak Vállalkozási specializáció. Látható, hogy legnagyobb számban a Nemzetközi gazdálkodási szak hallgatói töltötték ki a kérdőívet, arányuk a minta 23,3\%-a. 20\%-nál magasabb arányt képviselnek még a Gazdálkodási és menedzsment szakos és a Pénzügy számvitel szakos hallgatók.

\begin{tabular}{|l|l|l|l|l|l|l|l|l|l|}
\hline \multicolumn{1}{|c|}{ Neme } & \multicolumn{1}{|c|}{ GM } & PSZ & \multicolumn{1}{c|}{ NG } & KM & $\begin{array}{c}\text { PSZ- } \\
\text { FOSZ }\end{array}$ & VSZ & MBA & EET & BIOT \\
\hline Férfi & 17 & 10 & 10 & 6 & 4 & 11 & 2 & 0 & 0 \\
\hline Nő & 28 & 36 & 38 & 12 & 7 & 16 & 1 & 6 & 2 \\
\hline Összesen & 45 & 46 & 48 & 18 & 11 & 27 & 3 & 6 & 2 \\
\hline
\end{tabular}

2. táblázat: A minta nem és szak szerinti megoszlása (fö)

\section{Eredmények}

Az eredmények értékelésénél először a teljes mintára vonatkozó adatokat mutatom be és igyekszem az első kutatási kérdésemet megválaszolni. Az 1. ábra szemlélteti a válaszok megoszlását, pontosabban, hogy hány válaszadó adott 4, 5, 6... 28 pontot az adott személyiségvonásra (milyen mértékben gondolta magára nézve jellemzőnek a kérdőívben megfogalmazott állításokat).

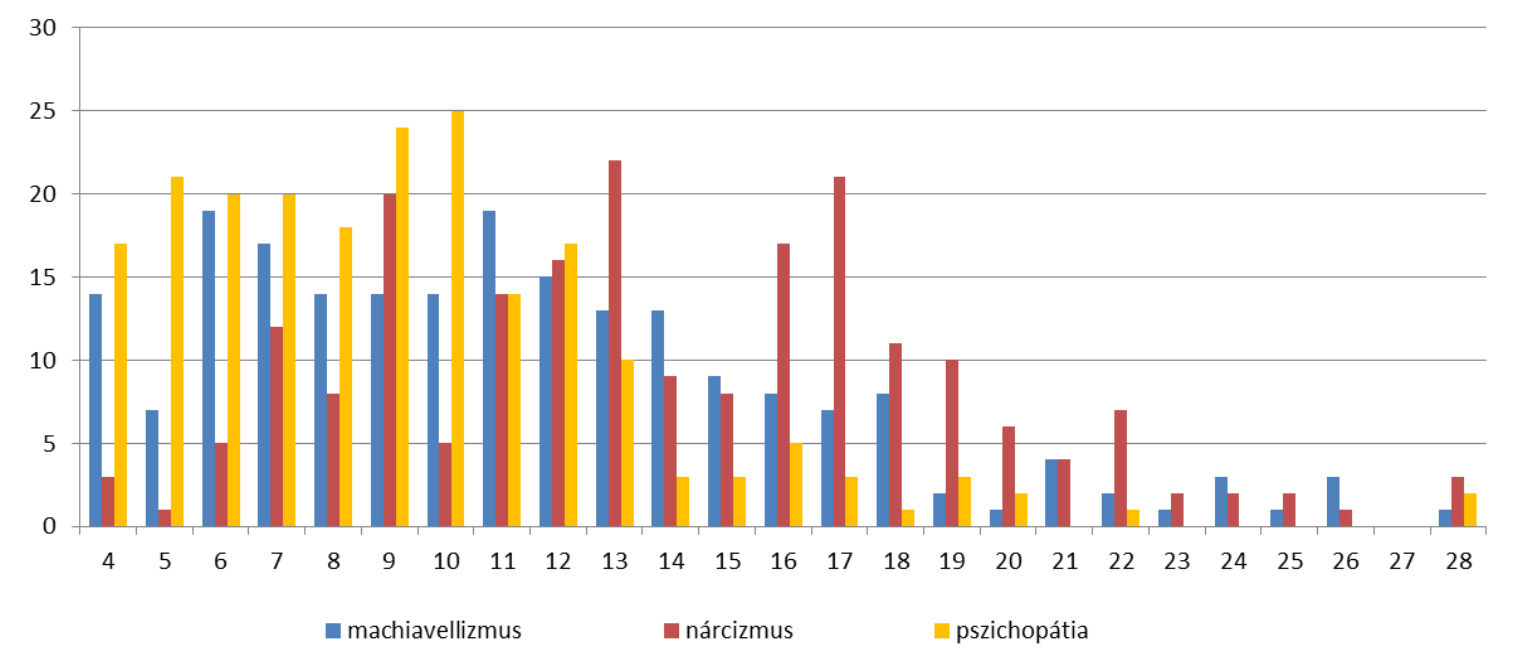

1. ábra: A machiavellizmusra, nárcizmusra és (fö pszichopátiára adott pontok gyakorisága)

Az ábrából kiolvasható, hogy a nárcizmus a leginkább, a pszichopátia legkevésbé jellemző a megkérdezettekre. A válaszadók jelentős része 15 pont alattira értékelte magát ezekben a jellemzőkben, de akad a mintában olyan is, akire erősen igazak a megállapítások. A 3. Táblázat azt mutatja meg, hogy a mintából hány fő (és hány \%) tartozik az erősen machiavellista, narcisztikus és pszichopata csoportba. Erős machiavellizmus jellemez 50 hallgatót $(23,9 \%), 25$ férfit, 25 nőt, erős 
narcisztikus személyiség 94 hallgató (45\%), 32 férfi, 62 nő és erős (szubklinikai) pszichopata 20 hallgató (9,6\%), 11 férfi, 9 nő.

\begin{tabular}{|l|l|l|l|l|l|l|}
\hline & \multicolumn{2}{|c|}{ Machiavellizmus } & \multicolumn{2}{c|}{ nárcizmus } & \multicolumn{2}{c|}{ pszichopátia } \\
\hline & fó & $\%$ & fó & $\%$ & fó & $\%$ \\
\hline $\begin{array}{l}15 \text { pontnál } \\
\text { kevesebb }\end{array}$ & 159 & 76,1 & 115 & 55,0 & 189 & 90,4 \\
\hline $\begin{array}{l}15 \text { pont vagy } \\
\text { több }\end{array}$ & 50 & 23,9 & 94 & 45,0 & 20 & 9,6 \\
\hline
\end{tabular}

3. táblázat: A Sötét Hármas jellemzók megjelenése a mintában

Mindhárom személyiségvonást egyszerre vizsgálva a megkérdezettek 82,9\%-a, azaz 174 fó nem érte el a 45 pontot, ami a Sötét Hármas tagságra utalna. Ugyanakkor jelentősnek mondható, hogy a hallgatók 17,1\%-át erősen jellemzik ezek a társadalmilag nemkívánatos tulajdonságok.

\begin{tabular}{|l|l|l|}
\hline \multirow{2}{*}{ Megnevezés } & \multicolumn{2}{|l|}{ Összesen } \\
\cline { 2 - 3 } & fő & $\%$ \\
\hline 45 pontnál kevesebb & 174 & 82,9 \\
\hline 45 pont, vagy több & 35 & 17,1 \\
\hline
\end{tabular}

4. táblázat: A Sötét hármas tagok száma és aránya a megkérdezettek körében

Ha kicsit szigorúbban, csak azokat sorolom a Sötét Hármas tagok közzé, akik mindhárom jellemzőben elérték a 15 pontot, akkor 12 ilyen személy van a mintában, a válaszadók 5,7\%-a, s közülük 7 férfi és 5 nő.

A második kutatási kérdésnél a férfiak és nők közötti különbségeket igyekeztem feltárni független mintás $t$-teszttel. Az 5. Táblázatban a férfiak és nők által elért átlag pontszámokat vetem össze és igazolom a jelentős eltéréseket. Mindhárom személyiségvonásnál és az összes pontszámnál is a férfiak átlaga magasabb. A nárcizmust kivéve az eltérések 1\%-on szignifikánsak.

Harmadik kutatási kérdésem az volt, hogy kimutathatók-e különbségek a szakok között? Pontosabban igazolható-e, hogy valamelyik szak hallgatói körében szignifikánsan eltérő mértékben jelennek meg a Sötét Hármas jellemzői. Feltevésem igazolására ANOVA elemzést végeztem. Statisztikailag nem találtam szignifikáns különbséget a három személyiségvonás megjelenésében a különböző szakokon tanuló hallgatói csoportok között. Hasonló eredményt hozott negyedik kutatási kérdésem, a különböző korosztályok vizsgálata is.

A 6. Táblázat azt mutatja, hogy a különböző szakok mintában szereplő hallgatóinak hány százalékára jellemzőek erősen a Sötét Hármas személyiségvonások. Az adatokból nem lehet mélyebb következtetésekre jutni, mivel több esetben az elemszám túl alacsony és statisztikailag bizonyítható 
összefüggéseket nem sikerült találnom, mégis érdekes szembesülni a bizonyos esetekben igen magas arányokkal.

\begin{tabular}{|l|l|l|l|l|l|}
\hline \multicolumn{2}{|l}{} & fó & átlag & szórás & t \\
\hline \multirow{2}{*}{ Machiavellizmus } & férfi & 60 & 13,33 & 5,061 & \multirow{2}{*}{$3,467^{* * *}$} \\
\cline { 2 - 5 } & nő & 148 & 10,63 & 5,111 & \\
\hline \multirow{3}{*}{ Nárcizmus } & férfi & 60 & 14,57 & 4,738 & \multirow{2}{*}{0,980} \\
\cline { 2 - 5 } & nő & 148 & 13,81 & 5,155 & \\
\hline \multirow{3}{*}{ Pszichopátia } & férfi & 60 & 11,00 & 4,419 & \multirow{2}{*}{$3,893^{* * *}$} \\
\cline { 2 - 5 } & nő & 148 & 8,61 & 3,824 & \\
\cline { 2 - 5 } & férfi & 60 & 38,90 & 11,744 & \multirow{2}{*}{$3,255^{* * *}$} \\
\cline { 2 - 5 } & nő & 148 & 33,05 & 11,733 & \\
\hline
\end{tabular}

5. táblázat: Férfiak és nők Dirty Dozen kérdốivvel nyert átlagpontjai

\begin{tabular}{|l|l|l|l|l|l|}
\hline \multicolumn{1}{|c|}{ Szak } & Machiavellizmus & Nárcizmus & Pszichopátia & $\begin{array}{c}45 \text { pont és } \\
\text { több }\end{array}$ & Sötét Hármas \\
\hline GM & $27 \%$ & $44 \%$ & $22 \%$ & $22 \%$ & $13 \%$ \\
\hline PSZ & $30 \%$ & $41 \%$ & $9 \%$ & $17 \%$ & $2 \%$ \\
\hline NG & $15 \%$ & $50 \%$ & $2 \%$ & $13 \%$ & $2 \%$ \\
\hline KM & $11 \%$ & $33 \%$ & $0 \%$ & $6 \%$ & $0 \%$ \\
\hline $\begin{array}{l}\text { PSZ- } \\
\text { FOSZ }\end{array}$ & $27 \%$ & $18 \%$ & $0 \%$ & $9 \%$ & $0 \%$ \\
\hline VSZ & $37 \%$ & $56 \%$ & $11 \%$ & $22 \%$ & $7 \%$ \\
\hline MBA & $33 \%$ & $67 \%$ & $0 \%$ & $0 \%$ & $0 \%$ \\
\hline EET & $0 \%$ & $33 \%$ & $0 \%$ & $0 \%$ & $0 \%$ \\
\hline BIOT & $0 \%$ & $100 \%$ & $0 \%$ & $50 \%$ & $0 \%$ \\
\hline
\end{tabular}

6. tábláza: Erốs Sötét Hármas személyiségvonásokkal rendelkezốk aránya a szakok mintában szerepló hallgatói körében

\section{Konklúzió}

Tanulmányom célja a Sötét Hármas személyiségvonások megjelenésének vizsgálata volt a Debreceni Egyetem Gazdaságtudományi Karának hallgatói körében. Írásomban röviden áttekintettem a 
machiavellizmus, nárcizmus és a pszichopátia legfontosabb ismérveit. A nemkívánatos jellemvonások mellett azokat is összegyüjtöttem, amelyek előnyt jelentenek a viselőjüknek. Végül a Sötét Hármas személyiségvonások megjelenésének gyakoriságával kapcsolatos néhány kutatási eredményt foglaltam össze. Öt kutatási kérdést fogalmaztam meg. Ezekre adott válaszokat foglalom össze röviden. Milyen mértékben jelennek meg a „Sötét Hármas” személyiségvonások a DE GTK általam vizsgált hallgatói körében?

A pszichopátián kívül nem találtam szakirodalmi adatokat a másik két jellemző megjelenésének gyakoriságára vonatkozóan. Boddy [15] véleménye szerint a népesség körében a szubklinikai pszichopaták aránya 1\% körüli. Más szerzők a Sötét Hármas tagok üzleti életben, nagy pénzügyi szervezetek menedzseri pozícióiban való gyakoribb megjelenésükre utalnak [6], [16]. Mintámban a válaszadók 9,6\% tartozik a pszichopaták csoportjába. A machiavellisták aránya 23,7\%, a narcisztikus személyeké 45,0\%. Véleményem szerint ezek igen magas arányok. Feltételezhető tehát, hogy a gazdaságtudományi képzési területek hallgatói között - akikből a nagyvállalatok jövendő menedzserei kerülnek majd ki - a normál népességhez képest gyakrabban jelennek meg ezek a jellemzők. Ezt a feltevést azonban szélesebb körű vizsgálatokkal lehet csak bizonyítani, vagy elvetni.

Kimutathatók-e különbségek férfiak és nők között?

Számos kutatás találta a Sötét Hármas jellemvonások megjelenését gyakoribbnak a férfiak körében [6], [8], [15], [16]. Ezt csak részben támasztják alá kutatási eredményeim. Mindhárom személyiségvonásnál a férfiak átlagpontszámai magasabbak, bár szignifikáns eltérést csak a machiavellizmus és pszichopátia esetén találtam. A vizsgált jellemvonásokban magas értékeket (15 pont, vagy több) elérő férfiak és nők aránya viszont a szakirodalomtól eltérően alakult. A mintában ugyanannyi machiavellista nőt mint férfit találtam, majdnem kétszerannyi nő, mint férfi bizonyult erősen narcisztikusnak, és csak a pszichopátia és a Sötét Hármas tagság esetén voltak többségben a férfiak (pszichopata 11 férfi, 9 nő, szigorúan vett Sötét Hármas tag 7 férfi, 5 nő). Eredményeim mögött meghúzódó lehetséges magyarázat, hogy a férfiak és nők aránya a mintámban 28,8%/71,2\%, ami erősen torzíthatja az eredményeket.

Kimutathatók-e különbségek a szakok között?

A szakok között ANOVA elemzéssel nem sikerült szignifikáns eltéréseket kimutatni, de az erős Sötét Hármas személyiségvonások megjelenésének bizonyos esetekben igen magas aránya további kutatási kérdések megfogalmazására késztet. Érdemes lenne magasabb elemszámokkal, az egyetem különböző szakjainak bevonásával összehasonlító vizsgálatokat végezni és statisztikailag igazolható összefüggéseket keresni ezen a területen.

Kimutathatóak-e különbségek a kor függvényében?

Nem találtam statisztikailag igazolható összefüggéseket a kor és az erős Sötét Hármas jellemzők között.

Az eredmények összhangban állnak-e a nemzetközi kutatásokban leírtakkal? 
Eredményeim több ponton összhangban állnak a szakirodalomból megismert adatokkal. Hallgatók körében végzett nemzetközi kutatások eredménye szerint [17] a Dirty Dozen teszttel elért Sötét Hármas átlag 36 pont, az én mintámban ez az érték 34,7 pont. machiavellizmus, pszichopátia és a Sötét Hármas összesített átlagértékei esetén is a férfiak átlagai voltak magasabbak, hasonlóan a nemzetközi kutatási eredményekhez [6], [8], [15], [16], ugyanakkor ezekkel az eredményekkel nem áll összhangban, hogy a mintámban sokkal gyakoribb volt az erős nárcizmus a nők esetén és a pszichopátia aránya majdnem tízszerese a szakirodalomban fellelhető értékeknek [15].

\section{Hivatkozások}

[1] Atkinson, R. L., Atkinson, R. C., Smith, E. E., Bem, D. J., Pszichológia, Osiris, Budapest, 1995. 387.

[2] Bakacsi, Gy., A szervezeti magatartás alapjai. Alaptankönyv Bachelor hallgatók számára, Semmelweis Kiadó, Budapest, 2015.

[3] Robbins, S. P., Judge, T. A., Essentials of Organizational Behaviour Thirteenth Edition, Global Edition, Pearson Education Limited, Harlow, England, 2016.

[4] Jonason, P. K., Webster, G. D., Schmitt, D. P., Li, N. P., Crysel, L. The Antihero in Popular Culture: Life History Theory and the Dark Triad Personality Traits, Review of General Psychology, American Psychological Association, 2012, Vol. 16, No. 2, 192-199.

[5] Jonason, P. K., Webster, G. D., The Dirty Dozen: A Concise Measure of the Dark Triad, Psychological Assessment, American Psychological Association, 2010, Vol. 22, No. 2, 420432.

[6] O’Boyle, Jr. E. H., Forsyth, D. R., Banks, G. C, McDaniel, M. A., A Meta-Analysis of the Dark Triad and Work Behavior: A Social Exchange Perspective, Journal of Applied Psychology, American Psychological Association 2012, Vol. 97, No. 3, 557-579.

[7] Paulhus, D. L., Williams, K. M., The Dark Triad of personality: Narcissism, Machiavellianism, and psychopathy, Journal of Research in Personality, 2002, Vol. 36, No. 6, 556-563

[8] Jonason, P. K., Slomski, S., Partyka, J., The Dark Triad at work: How toxic employees get their way, Personality and Individual Differences, 2012, Vol. 52, 449-453.

[9] Jones, D. N., Paulhus, D. L., Machiavellianism. In Leary, M. R., Hoyle, R. H. (Eds.), Handbook of individual differences in social Behaviour, New York, NY. Guilford Press, 2009.

[10] Morf, C. C., Rhodewalt, F., Unraveling the paradoxes of narcissism: A dynamic self-regulatory processing model. Psychological Inquiry, 2001, Vol. 12, 177-196.

[11] Galvin, B. M., Waldman, D. A., Balthazard, P., Visionary communication qualities as mediators of the relationship between narcissism and attributions of leader charisma, Personnel Psychology, 2010, Vol. 63, No. 3. 509-537. 
[12] Byrne, K. A., Worthy, D. A., Do Narcissists Make Better Decisions? An Investigation of Narcissism and Dynamic Decision-Making Performance, Personality and Individual Differences, 2013, Vol. 53, 112-117.

[13] Bushman, B. J., Baumeister, R. F., Thomaes, S., Ryu, E., Begeer, S., West, S. G., Looking Again, and Harder, for a Link Between Low Self-Esteem and Aggression, Journal of Personality, Vol. 77, 427-446.

[14] Hare, R. D., Neumann, C. D., Psychopathy: Assessment and Forensic Implications, Canadian Journal of Psychiatry, Vol. 54, 791-802

[15] Boddy, C. R., The Corporate Psychopaths Theory of the Global Financial Crisis. Journal of Business Ethics, 2011, Vol. 102, 255-259

[16] Twenge, J. M., Konrath, S., Foster, J. D., Campbell, W. K., Bushman, B. J., Egos Inflating Over Time: A Cross-Temporal Meta-Analysis of the Narcissistic Personality Inventory, Journal of Personality, 2008, Vol. 76, No. 4, 875-902

[17] Jonason, P. K., Kaufman, S. B., Webster, G. D., Geher, G., What Lies Beneath the Dark Triad Dirty Dozen: Varied Relations with the Big Five, Individual Differences Research 2013, Vol. 11, No. 2, 81-90 